\title{
Ocular hazards of playing squash rackets
}

\author{
D. V. INGRAM AND I. LEWKONIA \\ Moorfields Eye Hospital, High Holborn, London, W.C.I
}

Squash rackets is a game played at a fast pace, popular in over fifty countries, with an estimated half million players in Great Britain alone. It is played between two, or occasionally four, players in an enclosed court of specified dimensions, using rackets similar to but smaller than a tennis racket, and with a hollow black rubber ball $\mathrm{I} \frac{5}{8}$ in. in diameter and $\frac{3}{4} \mathrm{oz}$. in weight.

There has been a spectacular increase in the popularity of squash rackets during the last 20 years, and information suggests that it is now the country's fastest-growing sport (Spink, 1972). It is estimated that male players outnumber female players by five to one (Horry, i972).

It was our impression that ocular injury is a not uncommon occurrence amongst squash players, although a search of the literature revealed only passing references to the subject (Colson and Armour, 1961 ; Blonstein, 1964). It was hoped that our study would clarify this impression and also elucidate the various factors which might predispose to, or lessen the risk of, such injury.

\section{Findings}

We have examined twenty patients who sustained ocular injuries as a result of playing squash rackets, and also the case notes of one further patient, making a total of $2 \mathrm{I}$, all men.

A detailed ocular history was obtained from each of the patients examined. Enquiry was also made into the circumstances of the injury on the court, whether spectacles were worn, and whether the patients were right- or left-handed. A complete ocular examination was carried out, including assessment of the visual acuity, spectacle correction, slit-lamp microscopy, applanation tonometry, gonioscopy, fundus examination, and visual fields of each patient. An assessment of the severity of the injuries was made and expressed on a four-point scale (minor + to severe ++++ ). As far as could be ascertained, all had 'normal' corrected visual acuity in both eyes before injury.

\section{Case reports}

Table I records for each of the 2 I patients their age, date of injury, duration of playing before injury, whether right- or left-handed, which eye was injured, and a brief summary of the nature of the injury and its severity. 
Table I Details of 2 I patients

\begin{tabular}{|c|c|c|c|c|c|c|c|}
\hline $\begin{array}{l}\text { Patient } \\
\text { no. }\end{array}$ & $\begin{array}{l}\text { Age } \\
\text { (yrs) }\end{array}$ & $\begin{array}{l}\text { Injury } \\
\text { date }\end{array}$ & $\begin{array}{l}\text { Time } \\
\text { played }\end{array}$ & $\begin{array}{l}\text { Handed- } \\
\text { ness }\end{array}$ & Eye & Injury & Severity \\
\hline $\bar{I}$ & $3^{I}$ & May '69 & $7 \mathrm{yrs}$ & $\overline{\mathbf{R}}$ & $\bar{R}$ & $\begin{array}{l}\text { Orbital haematoma } \\
\text { Retinal dialysis }\end{array}$ & $+t+t$ \\
\hline 2 & 39 & Mar. '70 & $6 \mathrm{mths}$ & $\mathbf{R}$ & $\mathbf{L}$ & Corneal abrasion & + \\
\hline 3 & 32 & May '7o & 20 yrs & $\mathbf{R}$ & $\mathbf{L}$ & $\begin{array}{l}\text { Corneal laceration } \\
\text { Secondary uveitis }\end{array}$ & ++ \\
\hline 4 & 45 & Dec. '69 & 25 yrs & $\mathbf{R}$ & $\mathbf{R}$ & $\begin{array}{l}\text { Subconjunctival haemor- } \\
\text { rhage }\end{array}$ & + \\
\hline 5 & $4^{I}$ & Jan. '70 & 2 yrs & $\mathbf{R}$ & $\mathbf{L}$ & Retinal detachment & ++++ \\
\hline 6 & 28 & June '70 & $2 \mathrm{yrs}$ & $\mathbf{R}$ & $\mathbf{L}$ & $\begin{array}{l}\text { Ecchymosis } \\
\text { Hyphaema }\end{array}$ & ++ \\
\hline 7 & 24 & Aug. '70 & 3 wks & $\mathbf{R}$ & $\mathbf{R}$ & $\begin{array}{l}\text { Corneal abrasion } \\
\text { Commotio retinae }\end{array}$ & ++ \\
\hline 8 & 44 & 1958 & $14 \mathrm{yrs}$ & $\mathbf{R}$ & $\mathbf{L}$ & $\begin{array}{l}\text { Perforating with } \\
\text { vitreous loss }\end{array}$ & ++++ \\
\hline \multirow[t]{2}{*}{9} & 30 & July '68 & 5 yrs & $\mathbf{R}$ & $\mathbf{L}$ & Injection & \\
\hline & & & & & & Epiphora & + \\
\hline Io & 28 & Sept. '7o & 2 yrs & $\mathbf{R}$ & $\mathbf{R}$ & $\begin{array}{l}\text { Subluxated lens } \\
\text { Choroidal tears }\end{array}$ & ++++ \\
\hline II & 32 & Nov. '68 & Io yrs & $\mathbf{R}$ & $\mathbf{L}$ & $\begin{array}{l}\text { Perforating with } \\
\text { avulsion of iris }\end{array}$ & +++ \\
\hline 12 & 38 & 1967 & $8 \mathrm{yrs}$ & $\mathbf{R}$ & $\mathbf{R}$ & Ecchymosis & + \\
\hline 13 & 24 & 1968 & $16 \mathrm{yrs}$ & $\mathbf{R}$ & $\mathbf{L}$ & Hyphaema & ++ \\
\hline 14 & 47 & Dec. '68 & $30 \mathrm{yrs}$ & $\mathbf{R}$ & $\mathbf{L}$ & $\begin{array}{l}\text { Epistaxis } \\
\text { Commotio retinae }\end{array}$ & ++ \\
\hline 15 & 19 & Oct. '7o & $<\mathrm{I}$ yr & $\mathbf{R}$ & $\mathbf{R}$ & $\begin{array}{l}\text { Perforating with } \\
\text { uveal prolapse }\end{array}$ & +++ \\
\hline I6 & 26 & Oct. '7o & $8 \mathrm{yrs}$ & $\mathbf{R}$ & $\mathbf{L}$ & Haematoma of lid & + \\
\hline 17 & 34 & Oct. '7o & $17 \mathrm{yrs}$ & $\mathbf{L}$ & L & Hyphaema & ++ \\
\hline 18 & 40 & Jan. '7I & $20 \mathrm{yrs}$ & $\mathbf{R}$ & $\mathbf{L}$ & Haematoma of lids & + \\
\hline 19 & 26 & Jan. '7I & 9 yrs & $\mathbf{R}$ & $\mathbf{L}$ & $\begin{array}{l}\text { Canthal laceration } \\
\text { Corneal abrasion }\end{array}$ & + \\
\hline 20 & $3^{\mathrm{I}}$ & Oct. '7o & 8 wks & $\begin{array}{l}\text { R } \\
\text { (Oppo- } \\
\text { nent L) }\end{array}$ & $\mathbf{L}$ & $\begin{array}{l}\text { Perforating with } \\
\text { extrusion of ocular } \\
\text { contents }\end{array}$ & ++++ \\
\hline 21 & 32 & Feb. '68 & Unknown & $\mathbf{R}$ & $\mathbf{L}$ & $\begin{array}{l}\text { Hyphaema } \\
\text { Iridodialysis }\end{array}$ & +++ \\
\hline
\end{tabular}

Four of our patients sustained perforating injuries and details of these are presented below.

Case I (Patient 8). In $195^{8}$ a 44-year-old man who wore spectacles was hit by the follow-through of his opponent's racket. The glass shattered and he sustained superficial corneal lacerations in the lower cornea as well as perforating corneo-scleral injuries at two sites (10 and 4 o'clock) in the left eye. There was uveal and vitreous prolapse through the 4 o'clock injury site and at operation abscission of this prolapsed tissue was carried out with suturing of both perforating wounds.

\section{Examination (August, 1970)}

The visual acuity was $6 / 5$ and $\mathrm{N}_{5}$ in the right eye $\left(-\mathrm{I} \cdot 25 \mathrm{D}\right.$ sph., $-0.25 \mathrm{D}$ cyl., axis $\left.135^{\circ}\right)$ and $6 / 6$ and $\mathrm{N}_{5}$ in the left eye $\left(-\mathrm{I} \cdot 5 \mathrm{D}\right.$ sph., $-0.75 \mathrm{Dcyl}$, axis $\left.175^{\circ}\right)$. There were corneo-scleral scars with anterior synechiae at the ro o'clock position. There was a peripheral iridectomy at 4 o'clock through which the edge of the lens and its zonule were visible, and a small vitreous prolapse at the temporal margin of the pupil. The pressure in each eye was $14 \mathrm{~mm}$. $\mathrm{Hg}$ by applanation tonometry. In 
the lower half of the fundus of the injured eye there were extensive stippled pigmentary changes anterior to the equator. The peripheral field showed temporal constriction to $65^{\circ}$. Gonioscopically the angle of the anterior chamber appeared normal apart from the two sites of injury where ciliary processes and zonular fibres were visible.

Case 2 (Patient Ix). In 1968 a 32-year-old man who wore spectacles was hit by the ball whilst at a distance of 4 to $5 \mathrm{ft}$ from his opponent's racket. His spectacles were broken and he sustained a perforating corneo-scleral injury with iris prolapse, avulsion of most of the circumference of the iris from its root, and subluxation of the lens in the left eye. Abscission of the prolapsed iris and suturing of the corneo-scleral wound was performed.

Examination (September, 1970)

The visual acuity was $6 / 5$ and $N_{5}$ in the right eye ( $-7 \mathrm{D}$ sph., $-1 \cdot 25 \mathrm{D}$ cyl., axis $\left.15^{\circ}\right)$ and $6 / 36$ in the left eye ( $-3 \mathrm{D}$ sph., $-2.5 \mathrm{D}$ cyl., axis $\left.170^{\circ}\right)$. A scar of the perforating wound was present in the lower nasal quadrant with associated anterior synechiae. The atrophic remnants of the iris were attached to the ciliary body from 10.30 to I o'clock only. The lens had early cortical opacities and was subluxated, the anterior chamber being shallower nasally than temporally. The zonule was clearly visible and gonioscopically the angle was open throughout the circumference. He had been fitted with a scleral contact lens with which he had seen $6 / 18$ but his tolerance was poor and wear had been discontinued.

Case 3 (Patient 15). In 1970 a 19-year-old man who wore spectacles was struck by the racket of his opponent; the glass shattered and he sustained extensive lacerations of the lids, a perforating corneo-scleral wound, and uveal and vitreous prolapse of the right eye. There was an extensive hyphaema. At operation, the uveal tissue was abscised and the wound sutured. Glass was removed from under a triangular skin and muscle flap of the upper eyelid before this was sutured in layers. A lower lid laceration was also sutured. The hyphaema absorbed over the course of 5 days and the vitreous haemorrhage and commotio retinae which were then evident slowly resolved.

Examination (June, 1971)

The visual acuity was $6 / 24$ in the right eye $\left(-2 \cdot 25 \mathrm{D}\right.$ sph., $-\mathrm{I} \mathrm{D}$ cyl., axis $\left.30^{\circ}\right)$ and $6 / 6$ and $\mathrm{N}_{5}$ in the left eye $\left(-1 \cdot 25 \mathrm{D}\right.$ sph., $-0.5 \mathrm{D}$ cyl., axis $\left.90^{\circ}\right)$. This improved to $6 / 12$ in the right eye with a corneal contact lens which he wears satisfactorily. There were healed wounds in the sites described, an iridectomy, and minimal pigmentary changes in the temporal retinal periphery. The intraocular pressures were $\mathrm{I} 5$ and $13 \mathrm{~mm}$. $\mathrm{Hg}$ in the right and left eye respectively by applanation tonometry.

Case 4 (Patient 20). In 1970 a 3 I-year-old man who wore spectacles was struck by his left-handed opponent's racket. The broken glass inflicted extensive lacerations, perforating the globe and the lower lid of the left eye. At operation the eye was seen to be aphakic with extrusion of most of the ocular contents. Evisceration was carried out as a primary procedure and the lid laceration sutured. The right eye was normal and visual acuity was $6 / 4$ corrected for a low degree of compound myopic astigmatism.

\section{Comment}

Fourteen of our patients sustained more than minor $(+)$ injuries. Table II relates the final visual acuity in the fourteen patients to the severity of the injury and indicates whether the injury was caused by the ball or racket, whether glasses were worn whilst playing and indicates the four patients sustaining perforating injuries. It can be seen that all four of these patients were spectacle wearers. In seven cases the corrected visual acuity was less than $6 / 6$ in the affected eye at the final examination. Only one of the patients with perforating injuries retained a visual acuity of $6 / 6$. 
Table II Details of the fourteen more severely injured patients

\begin{tabular}{|c|c|c|c|c|c|}
\hline Patient no. & Final visual acuity & Severity & Injured by & Glasses & Perforating \\
\hline $\mathbf{I}$ & $6 / 12$ & ++++ & Ball & - & No \\
\hline 3 & $6 / 5$ & ++ & Racket & $<-2.0$ & No \\
\hline 5 & $6 / 12$ & ++++ & - & $>-10.0$ & No \\
\hline 6 & $6 / 4$ & ++ & Ball & - & No \\
\hline 7 & $6 / 5$ & ++ & Ball & - & No \\
\hline 8 & $6 / 6$ & $++t+$ & Racket & $<-2.0$ & Yes \\
\hline 10 & H.M. & +++ & Ball & - & No \\
\hline I I & $6 / 36$ & ++++ & Ball & -7.0 & Yes \\
\hline I3 & $6 / 5$ & ++ & Racket & $<-3.0$ & No \\
\hline 14 & $6 / 6$ & ++ & Racket & $<-3.0$ & No \\
\hline 15 & $6 / 12$ & +++ & Racket & $<-3.0$ & Yes \\
\hline 17 & $6 / 5$ & ++ & Ball & - & No \\
\hline 20 & - & ++++ & Racket & $<-3.0$ & Yes \\
\hline $2 \mathrm{I}$ & $6 / 9$ & +++ & Ball & - & No \\
\hline
\end{tabular}

It should be noted that all the spectacle wearers were myopes and that five out of seven of the most severely injured patients were spectacle wearers. No spectacle wearer had only a minor $(+)$ injury. Patient 5 was not actually hit whilst playing squash, but developed a retinal detachment during a game.

\section{Discussion}

The risk of ocular injury has been described in many sports, for example boxing (Doggart, 1955), golf (Millar, I967), hockey (Kaplan, 196r), and soccer (Dal Monte and Barcaroli, 1965). Little attention has, however, been payed to the hazards of squash rackets, although Colson and Armour ( $196 \mathrm{I}$ ) call it " a surprisingly accident-free sport". Blonstein (1964) has seen three cases of retinal detachment as a result of squash rackets.

Our findings demonstrate that injuries sustained while playing squash rackets cover a wide spectrum of severity and may have serious consequences to the eye. We have seen no case of bony injury and no intraocular foreign body, although glass has been removed from lacerated wounds of the lids. The ball or racket may cause serious injury but the wearing of spectacles enhances the hazards of injury by either.

It is suggested that players who need spectacles should always wear 'safety' lenses, either plastic, or glass of toughened or laminated design. Gyorffy (I95I) has described injuries in which the eye has actually been protected by a contact lens, and it is possible that the use of such lenses, either of conventional plastics or the newer hydrophilic gels which dispense with the need for spectacles, would reduce the risk of injury while playing squash rackets.

\section{Summary}

2 I cases of ocular injury are presented in patients who sustained trauma while playing squash rackets. The high incidence of severe injury in spectacle wearers among the patients is stressed. Squash players should be advised to wear safety lenses if they require spectacles. 
Our thanks are due to the consultant staff of Moorfields Eye Hospital, and also to Mr. R. S. E. Brewerton and Mr. G. V. Catford for their permission to publish details of cases under their care. We also wish to acknowledge the assistance given by Mr. J. H. Horry of 'The Squash Rackets Association' and Mr. A. H. Spink of the Federation of British Manufacturers of Sports and Games Limited.

\section{References}

BLonstein, J. L. (1964) In "Injury in Sport", ed. J. R. Armstrong and W. E. Tucker, p. 164. Staples Press, London

colson, J. H. C., and ARmour, w. J. (196r) "Sports Injuries and Their Treatment", p. 58. Stanley Paul, London

DAl mONte, A., and barcaroli, I. (1965) Gazz. int. Med. Chir., 70, I338

DOGgart, J. H. (1955) A.M.A. Arch. Ophthal., 54, $16 \mathrm{r}$

GYORFF, ST. v. (1951) Ophthalmologica (Basel), 122, 344

HORRY, J. (1972) Personal communication

Kaplan, A. 1. (196I) Vestn. Oftal., 74, No. 4, p. $5^{\text {I }}$

MILlAR, G. T. (1967) Amer. F. Ophthal., 64, 74I

SPINK, A. H. (1972) Personal communication 